\title{
Substrates Formulated with Biochar for Seedling Production of Moringa oleifera Lam.
}

\author{
Tássia Fernanda Santos Neri Soares ${ }^{1}$, Idamar da Silva Lima², André Quintão de Almeida ${ }^{2}$, \\ Maria Isidoria da Silva Gonzaga ${ }^{2}$, Camila Andrade Fialho ${ }^{1}$, Ingrid Luciana Rodrigues Gomes ${ }^{2}$ \\ $\&$ Wendel de Melo Massaranduba ${ }^{2}$ \\ ${ }^{1}$ Departmento de Fitotecnia, Universidade Federal de Viçosa, Viçosa, Minas Gerais, Brazil \\ ${ }^{2}$ Departamento de Agronomia, Universidade Federal de Sergipe, São Cristóvão, Sergipe, Brazil \\ Correspondence: Tássia Fernanda Santos Neri Soares, Departmento de Fitotecnia, Universidade Federal de \\ Viçosa, Viçosa, Minas Gerais, Brazil. Tel: 55-31-3899-2619. E-mail: tassia.soares@ufv.br
}

Received: September 22, 2018

Accepted: January 7, 2019

Online Published: March 15, 2019

doi:10.5539/jas.v11n4p515

URL: https://doi.org/10.5539/jas.v11n4p515

\begin{abstract}
Moringa oleifera is an allogamous plant that is propagated by seeds and cuttings, rich in vitamin A and C, phosphorus, calcium and proteins. However, its best propagation form for the large-scale production is still unknown, as well the most suitable substrate for seedling production. Production of forest species seedlings with a high quality is directly related to physical and chemical substrates properties. Using biochar as substrate for seedlings production is an economical and sustainable solution for this proposal. The aim of this study was to evaluate the influence of three biochar types, in two concentrations, for production of Moringa oleifera seedlings. Three types of substrates were formulated using residues of dry coconut shells, sewage sludge and orange bagasse. The experiment was carried out in a greenhouse, installed in a completely randomized design, consisting of seven treatments (substrates formulated with biochar in two doses, 1 and 2\%) and the control, with four replicates, totalizing 28 seedlings. One month after sowing, the seedlings were evaluated biweekly for 60 days in relation to stem base diameter, shoot heigh, leaves number, shoot dry matter, root dry matter, total seedling dry matter and Dickson Quality Index. The substrate formulated using sewage sludge biochar at $2 \%$ provided a greater increasing in shoot dry matter. This concentration improved seedling height and stem base diameter in 10.5 and $0.83 \mathrm{~mm}$, respectively, compared to the control. In general, biochar improved physical and chemical soil quality, promoting a better $M$. oleifera seedlings development.
\end{abstract}

Keywords: forest species, silviculture, diameter, height, soil properties

\section{Introduction}

Moringa oleifera Lam., belongs to Moringaceae family, composed of only one genus (Moringa). It is a native species from Northern India that grows normally in several tropical countries. In addition, M. oleifera grows rapidly and survives on poor soils. It is easily propagated and adapted to a wide range of soils. For being drought tolerant, requires less attention during long drought periods. This species is rich in vitamins $\mathrm{A}$ and $\mathrm{C}$, phosphorus, calcium, and protein. It has also diversified uses, especially in parks and gardens ornamentation, animal feed, human food supplementation and medicine. Furthermore, highlights $M$. oleifera uses for biological decontamination of water supply (Vieira et al., 2008; Santos et al., 2011; Agustini et al., 2015).

During plant growth process, choosing an inadequate substrate may affect seed germination and seedling establishment, which can lead to reduction in plant production quality. Consequently, the material used for composing the substrate needs to considerate variations in physical, chemical and biological soil properties. So that, characteristics such as soil structure, aeration, water retention and pathogens contamination are important in order to determine the best materials mix to compose a substrate (Silva et al., 2011). Moreover, the ideal substrate should have a low cost and be available in large quantities. For this reason, using industrial waste is a sustainable agricultural practice that aims to minimize environmental impact and improve simultaneously seedling production quality (Neves et al., 2010).

The substrate compounds obtained from natural materials may not only supply soil nutrients properly, but also provide a reuse in subsequent plantations as an alternative to minimize production costs and reach gains in 
productivity (Petter et al., 2012). However, a higher degradation rates of these materials limit their beneficial effects over time, in which can be mitigated when the waste is treated through carbonization process before being used as a party of the substrate mix.

Biochar produced through pyrolysis process considered as a soil conditioner may provide increases in soil biomass, carbon fixation, nutritional balance and filtration of percolating soil water. In fact, its capacity of being highly stable in soil contribute to improvements in chemical, physical and biological soil properties (Trazzi et al., 2016; Petter \& Madari, 2012). As a result, biochar can improve soil commercial substrates and contribute to reduction of chemical fertilizers uses, being a sustainable and low-cost alternative to increase seedlings quality (Lima et al., 2013).

Regarding different biochar uses, new studies are necessary in order to identify soil and biochar properties that help to maximize its application on agriculture production (Lima et al., 2016). To know more about biochar characteristics is important to avoid unwanted effects on soil fertility (Novak et al., 2014), such as excessive pH increase and nutrient unavailability.

Due to the Moringa importance and necessity of deeply studies related to biochar for forest seedling production, this work aims to evaluate the influence of three biochar types, in two concentrations, for production of $M$. oleifera seedlings.

\section{Method}

\subsection{Study Area}

The study was carried out at Universidade Federal de Sergipe, located in São Cristóvão, Sergipe, Brazil. The production of $M$. oleifera seedlings was conducted in an air circulation oven with temperature control, in which the cooling system was activated when the internal temperature reached $28^{\circ} \mathrm{C}$.

The soil used in this study was obtained from a surface horizon, classified as Red Yellow Argissolo, according to the Water Resources Digital Atlas of Sergipe State (2013). After collected, the soil was air dried, dewormed and sieved in a $2 \mathrm{~mm}$ mesh. Samples of this material were submitted to physical analysis, density and grain size composition, according to Donagema et al. (2011), and chemical analysis, potassium (P), calcium (Ca), magnesium $(\mathrm{Mg})$, aluminum $(\mathrm{Al})$, organic matter $(\mathrm{OM}), \mathrm{pH}$, electrical conductivity (EC), effective cation exchange capacity $\left(\mathrm{CEC}_{\text {effective}}\right)$, following methodology proposed by Silva (2009) (Table 1).

Table 1. Physical and chemical properties of a surface horizon soil, classified as red yellow argissolo used in this study

\begin{tabular}{|c|c|c|}
\hline Element & Unit & Result \\
\hline $\mathrm{pH}$ & - & 4.64 \\
\hline $\mathrm{EC}$ & $\mathrm{mS} \mathrm{cm}^{-1}$ at $25^{\circ} \mathrm{C}$ & 0.063 \\
\hline $\mathrm{OM}$ & \multirow{2}{*}{$\mathrm{g} \mathrm{dm}^{-3}$} & 11.06 \\
\hline $\mathrm{C}$ & & 6.36 \\
\hline P Melich & \multirow{2}{*}{$\mathrm{mg} \mathrm{dm}{ }^{-3}$} & 1.82 \\
\hline $\mathrm{K}$ & & 25.40 \\
\hline $\mathrm{Al}$ & \multirow{6}{*}{$\mathrm{cmol} \mathrm{dm}^{-3}$} & 0.45 \\
\hline $\mathrm{K}$ & & 0.06 \\
\hline $\mathrm{Ca}$ & & 0.72 \\
\hline $\mathrm{Mg}$ & & 0.65 \\
\hline SB & & 1.43 \\
\hline $\mathrm{CEC}_{\text {effective }}$ & & 1.88 \\
\hline Base Saturation & $\%$ & 76.13 \\
\hline Density & $\mathrm{g} \mathrm{cm}^{-3}$ & 1.39 \\
\hline Sand & \multirow{3}{*}{$\%$} & 71.57 \\
\hline Silt & & 13.43 \\
\hline Clay & & 15.00 \\
\hline Textural Classification & - & Franco Sand \\
\hline
\end{tabular}




\subsection{Biochar Production}

Biochars were produced in a furnace adapted using a model developed by the International Biocarbon Initiative (IBI). The Top LidUp Draft (TLUD) model uses chimney as a second phase of burning to eliminate volatile products produced by pyrolysis. The pyrolysis process was conducted during 2 hours for sweage sludge biochar and 1 hour for dry coconut shells and orange bagasse. The temperature used was around $400-500{ }^{\circ} \mathrm{C}$. Both vapors and non-condensable gases were burned to provide energy and to continue the carbonization process.

Biochars used for composing the substrates were submitted to laboratory analysis, in which the moisture content was determined on an oven-dry mass basis. Volatile matter, ash and fixed carbon were carried out in a muffle oven, following a methodology described by ABNT (1986) (Table 2). Determination of P and K available concentrations, $\mathrm{pH}$ and electrical conductivity was according to methodology used in the soil fertility determination. For Total Nitrogen (Nt) analysis was used a methodology to determine the plant tissue composition (Silva, 2009).

Table 2. Characteristics of biochars obtained with coconut shell, orange bagasse and sewage sludge

\begin{tabular}{|c|c|c|c|c|}
\hline Element & Unit & Coconut Shell & Orange Bagasse & Sewage Sludge \\
\hline $\mathrm{pH}$ & - & 9.88 & 10.33 & 7.28 \\
\hline EC & $\mathrm{mS} \mathrm{cm}{ }^{-1}$ at $25^{\circ} \mathrm{C}$ & 2.19 & 2.75 & 10.39 \\
\hline Total Carbon (Dichromate) & & 62.40 & 62.30 & 34.04 \\
\hline $\mathrm{N}_{\text {Total }}$ & & 0.45 & 1.18 & 1.60 \\
\hline Moisture Content & 0 & 8.20 & 7.55 & 3.95 \\
\hline Ash & $\%$ & 8.97 & 9.75 & 48.13 \\
\hline Volatile matter & & 36.99 & 41.63 & 25.97 \\
\hline Fixed Carbon & & 54.04 & 48.51 & 25.40 \\
\hline C/N Ratio & - & 0.72 & 52.78 & 21.28 \\
\hline $\mathrm{P}_{\text {available }}$ & $\sigma_{k \sigma^{-1}}$ & 0.65 & 5.20 & 10.60 \\
\hline $\mathrm{K}_{\text {available }}$ & g kg & 1.43 & 36.70 & 2.90 \\
\hline
\end{tabular}

\subsection{Substrates Formulation}

Three types of substrates were formulated using a mixture of soil and biochar, produced from dry coconut shell, orange bagasse and sewage sludge. This biochar was obtained by means of production residues collected at rural property, waste generated by snack bars of the university and waste generated by sewage treatment provided by Sergipe water supply company, respectively.

After substrates being prepared, those residues samples were collected and sent to the Soil Analysis Laboratory of Federal University of Sergipe to perform the chemical and physical analysis in order to determinate available nutrient contents (Silva, 2009; MAPA, 2007), since most of the substrate is composed of soil. Then, it was evaluated the total porosity $\left(\mathrm{P}_{\text {Total }}\right)$, macroporosity $\left(\right.$ Macro $\left._{\mathrm{P}}\right)$, microporosity $\left(\right.$ Micro $\left._{\mathrm{P}}\right)$, field capacity at $33 \mathrm{kPa}$ (FC), permanent wilt point at $1500 \mathrm{kPa}(\mathrm{PWP})$ and total soil water availability $\left(\mathrm{WA}_{\text {Total }}\right)$.

\subsection{Trial Design}

The experiment was carried out in a completely randomized design with seven treatments: dry coconut shell biochar, sewage sludge biochar, orange bagasse biochar at 1 and $2 \%$ and the control (soil without biochar). Four replicates were used for each treatment with a total of 28 seedlings.

Four seeds were sown in pots with a $1.5 \mathrm{~L}$ capacity, containing $2 \mathrm{~kg}$ of soil plus the biochar. After that, the roughing was done in order to leave the most vigorous plant. The filled pots with soil and biochar were irrigated and kept wet until the sowing day. This practice is necessary to induce bio-coal reactions with the soil to promote a balance of a system. Soil moisture was maintained close to the field capacity to minimize possible water stress.

One month after sowing, seedlings were evaluated biweekly for 60 days by measuring steam base diameter, shoot height and number of leaves. To measure seedlings steam diameter, a digital caliper with millimetric precision was used. Seedlings height were measured by means of a ruler from soil surface to the apical plant bud. After measure those growth parameters, seedlings were separated into shoot and root, washed and placed in paper bags for drying in an air circulating oven at $65{ }^{\circ} \mathrm{C}$ until reaching a constant mass. After that, the roots and 
shoots dry matter were weighed. The number of was given manually, starting with basal leaves until the last one totally opened (Carneiro, 1995).

At the end of the experiment, root dry matter (RDM), shoot dry matter (SDM), total seedling dry matter (TDM), ratio $\mathrm{RDM} / \mathrm{SDM}$ and Dickson Quality Index (DQI) were obtained by the equation below (DICKSON et al., 1960):

$$
\mathrm{DQI}=\mathrm{TDM} /(\mathrm{SH} / \mathrm{SBD})+(\mathrm{SDM} / \mathrm{RDM})
$$

where, $\operatorname{TDM}_{(\mathrm{g})}$ is the Total Dry Matter, $\mathrm{SH}_{(\mathrm{cm})}$ is the Shoot Height, $\mathrm{SBD}_{(\mathrm{mm})}$ is the Stem Base Diameter, $\mathrm{SDM}_{(\mathrm{g})}$ is the Shoot Dry Matter and $\mathrm{RDM}_{(\mathrm{g})}$ is the Root Dry Matter.

\subsection{Statistical Analysis}

The data were submitted to analysis of variance (ANOVA) and Tukey's multiple range tests $(\mathrm{P}<0.05)$, using software R 3.2.2 (R Development Core Team. 2015). Variability in the biochar types treatment means was also expressed as the standard deviation of four replicates.

\section{Results and Discussion}

\subsection{Effects of Biochar on Chemical Soil Properties}

The addition of different biochar types in the soil had a significant impact on chemical soil properties of the $M$. oleifera seedlings substrates (Table 3). In general, all the biochars improved chemical characteristics compared to the control (soil without biochar), mainly pH, EC, CEC, Sum of Base (SB) and Base Saturation (BS).

Table 3. Chemical porperties of Moringa oleifera substrates treated with biochar form coconut shell (CSB), orange bagasse (OBB) and sewage sludge (SSB), at 1 and $2 \%$

\begin{tabular}{|c|c|c|c|c|c|c|c|c|}
\hline \multirow{2}{*}{\multicolumn{2}{|c|}{ Chemical Porperties }} & \multicolumn{7}{|c|}{ Biochar treatment } \\
\hline & & Control & CSB $1 \%$ & CSB $2 \%$ & SSB $1 \%$ & SSB $2 \%$ & OBB $1 \%$ & OBB $2 \%$ \\
\hline $\mathrm{pH}$ & - & $4.9^{\mathrm{e}}$ & $5.4^{\mathrm{cd}}$ & $5.9^{\mathrm{b}}$ & $5.3^{\mathrm{d}}$ & $5.6^{\mathrm{c}}$ & $6.0^{\mathrm{b}}$ & $6.7^{\mathrm{a}}$ \\
\hline $\mathrm{EC}$ & $\mathrm{mS} \mathrm{cm}^{-1}$ & $549.4^{\mathrm{b}}$ & $818.8^{\mathrm{ab}}$ & $1024.8^{\mathrm{a}}$ & $847.4^{\mathrm{ab}-}$ & $862.7^{\mathrm{ab}}$ & $611.0 \mathrm{a}^{-}$ & $913.8^{\mathrm{a} b}$ \\
\hline $\mathrm{P}$ & \multirow{3}{*}{$\mathrm{mg} \mathrm{dm} \mathrm{m}^{-3}$} & $7.8^{\mathrm{d}^{-}}$ & $8.3^{\mathrm{d}}$ & $9.5^{\mathrm{d}}$ & $28.3^{\mathrm{b}}$ & $44.9^{\mathrm{a}}$ & $16.9^{\mathrm{c}}$ & $27.0^{\mathrm{b}}$ \\
\hline $\mathrm{K}$ & & $31.5^{\mathrm{c}}$ & $199.8^{\mathrm{c}}$ & $428.0^{\mathrm{b}}$ & $40.0^{\mathrm{c}}$ & $47.5^{\mathrm{c}}$ & $427.0^{\mathrm{b}}$ & $875.3^{\mathrm{a}}$ \\
\hline $\mathrm{Na}$ & & $98.4^{\mathrm{d}}$ & $410.4^{\mathrm{a}}$ & $297.1^{\mathrm{ab}}$ & $215.4^{\mathrm{bcd}}$ & $242.9^{\mathrm{bc}}$ & $107.6^{\mathrm{cd}}$ & $155.9^{\mathrm{cd}}$ \\
\hline $\mathrm{Ca}$ & \multirow{6}{*}{$\mathrm{cmol} \mathrm{dm}^{-3}$} & $1.9^{\mathrm{c}}$ & $1.6^{\mathrm{d}}$ & $1.4^{\mathrm{d}}$ & $2.6^{\mathrm{b}^{-}}$ & $2.9^{\mathrm{a}}$ & $2.0^{\mathrm{c}}$ & $1.9^{\mathrm{c}}$ \\
\hline $\mathrm{Mg}$ & & $0.8^{\mathrm{b}}$ & $0.8^{\mathrm{b}}$ & $0.8^{\mathrm{b}}$ & $1.1^{\mathrm{a}}$ & $1.2^{\mathrm{a}}$ & $1.0^{\mathrm{ab}}$ & $1.0^{\mathrm{ab}}$ \\
\hline $\mathrm{Al}$ & & $0.08^{\mathrm{ns}}$ & $0.09^{\mathrm{ns}}$ & $0.02^{\mathrm{ns}}$ & $0.02^{\mathrm{ns}}$ & $0.00^{\mathrm{ns}}$ & $0.02^{\mathrm{ns}}$ & $0.00^{\mathrm{ns}}$ \\
\hline $\mathrm{H}+\mathrm{Al}$ & & $1.43^{\mathrm{a}}$ & $1.09^{\mathrm{ab}}$ & $0.80^{\mathrm{b}}$ & $1.43^{\mathrm{a}}$ & $1.42^{\mathrm{a}}$ & $1.21^{\mathrm{ab}}$ & $0.97^{\mathrm{ab}}$ \\
\hline CEC & & $4.66^{\mathrm{c}}$ & $5.30^{\mathrm{bc}}$ & $5.84^{\mathrm{abc}}$ & $6.20^{\mathrm{ab}}$ & $6.72^{\mathrm{a}}$ & $5.77^{\mathrm{abc}}$ & $6.84^{\mathrm{a}}$ \\
\hline SB & & $3.23^{\mathrm{c}}$ & $4.22^{\mathrm{bc}}$ & $5.05^{\mathrm{ab}}$ & $4.77^{\mathrm{ab}}$ & $5.30^{\mathrm{ab}}$ & $4.56^{\mathrm{b}}$ & $5.87^{\mathrm{a}}$ \\
\hline $\mathrm{C}$ & $\mathrm{g} \mathrm{dm}^{-3}$ & $0.55^{\mathrm{c}}$ & $1.00^{\mathrm{b}}$ & $1.85^{\mathrm{a}}$ & $1.67^{\mathrm{a}}$ & $1.70^{\mathrm{a}}$ & $1.70^{\mathrm{a}}$ & $1.97^{\mathrm{a}}$ \\
\hline
\end{tabular}

Note. Means followed by the same letter within a row are not statistically different, according to the Tukey test at $5 \%$ probability.

All biochars applied to the substrates raised soil $\mathrm{pH}$ by $0.4-1.8$ units. However, only CSB $2 \%$, SSB $2 \%$ and OBB $1 \%$ reached $\mathrm{pH}$ values between 5.5 and 6.5 , considered appropriated to forest seedlings production (Gonçalves \& Poggiani, 1996). Dai et al. (2013) reported that pineapple peel biochar at 1 and 3\% increased soil pH by 1.13 and 2.16 units compared with the control biochar treatment. Similarly, Zhang et al., (2015) indicated that soil pH had increased after application of peanut hull, rice and rape straw biochar by $0.70,0.92$ and 0.63 units, respectively. Raising soil $\mathrm{pH}$ could alter the form that nutrients are available for plants and make some element root absorption easier (Ding et al., 2016). However, the effects of biochar in the soil $\mathrm{pH}$ depends on pyrolysis process and biochar type (Ok et al., 2016).

The biochar application to the soil provided a great difference between $\mathrm{BC}$ types according to EC parameter. The CSB 2\% and OBB 2\% substrates showed the higest EC in the soil. A higher EC value is associated with a higher amount of leached salts in the solution. So that, salt excess in the soil may interfere in a germination process and seedling growth due to the necessity of a greater energy to absorve water, leading to damages in metabolic process (Tomé Júnior, 1997). 
Applying biochar to the soil increased significantly some plant elemental concentracions, such as $\mathrm{P}, \mathrm{K}, \mathrm{Na}, \mathrm{Ca}$ and $\mathrm{Mg}$. The increase of $\mathrm{P}$ avaliable in the soil could be explained by a higher $\mathrm{P}$ content in the biochar applied or due to an increase of CEC, leading to a lower Al content in acidic soils (Ok et al., 2016). The CEC was significantly affected by the addition of OBB $2 \%$, SSB 1 and $2 \%$ tratments. The beneficial effects of the biochar application on CEC have been widely reported (e.g. Vaccari et al., 2012; Kloss et al., 2014; Abujabhah et al., 2015; Hasen et al., 2016).

\subsection{Effects of Biochar on Physical Soil Properties}

The biochar influenced all soil physical properties analyzed of formulated substrates, except for macroporosity (Table 4). The CSB biochar type at both concentration and OBB at $2 \%$ improved total porosity when compared with the control. Only biochar using dry coconut shells increased significantly the total porosity and microporosity at the same time, but had no significant effect on macroporosity. These results disagreed with those of Pratiwi and Shinogi (2016) who reported that biochar amendment using rice husk at $4 \%$ raised significantly soil macropores, but had no significant effect on micropores. Although, these authors indicate that macropores had considerably decreased during the growing period while increased micropores.

Table 4. Physical porperties of Moringa oleifera substrates treated with biochar form coconut shell (CSB), orange bagasse (OBB) and sewage sludge (SSB), at 1 and $2 \%$

\begin{tabular}{|c|c|c|c|c|c|c|c|c|}
\hline \multirow{2}{*}{\multicolumn{2}{|c|}{ Soil porperties }} & \multicolumn{7}{|c|}{ Biochar treatment } \\
\hline & & \multirow{2}{*}{$\frac{\text { Control }}{28.95^{\mathrm{c}}}$} & \multirow{2}{*}{$\begin{array}{l}\text { CSB 1\% } \\
32.88^{\mathrm{b}}\end{array}$} & \multirow{2}{*}{$\frac{\text { CSB } 2 \%}{39.34^{\mathrm{a}}}$} & \multirow{2}{*}{$\begin{array}{l}\text { SSB 1\% } \\
28.98^{\mathrm{c}}\end{array}$} & \multirow{2}{*}{$\begin{array}{l}\text { SSB } 2 \% \\
30.29^{\mathrm{bc}}\end{array}$} & \multirow{2}{*}{$\frac{\text { OBB } 1 \%}{30.09^{\text {bc }}}$} & \multirow{2}{*}{$\frac{\mathrm{OBB} 2 \%}{32.2^{\mathrm{b}}}$} \\
\hline $\mathrm{P}_{\text {Total }}$ & & & & & & & & \\
\hline Macro $_{P}$ & & $9.57^{\mathrm{a}}$ & $10.04^{\mathrm{a}}$ & $13.67^{\mathrm{a}}$ & $12.00^{\mathrm{a}}$ & $12.19^{\mathrm{a}}$ & $11.44^{\mathrm{a}}$ & $13.92^{\mathrm{a}}$ \\
\hline Micro $_{P}$ & $\%$ & $19.37^{\mathrm{c}}$ & $22.85^{\mathrm{b}}$ & $25.68^{\mathrm{a}}$ & $16.99^{\mathrm{c}}$ & $18.10^{\mathrm{c}}$ & $18.65^{\mathrm{c}}$ & $18.33^{\mathrm{c}}$ \\
\hline $\mathrm{FC}$ & & $8.02^{\mathrm{c}}$ & $9.04^{\mathrm{c}}$ & $13.18^{\mathrm{a}}$ & $8.71^{\mathrm{c}}$ & $9.21^{\mathrm{c}}$ & $8.18^{\mathrm{c}}$ & $11.21^{\mathrm{b}}$ \\
\hline PWP & & $5.22^{\mathrm{de}}$ & $7.61^{\mathrm{c}}$ & $11.40^{\mathrm{a}}$ & $4.12^{\mathrm{e}}$ & $5.01^{\mathrm{de}}$ & $5.80^{\mathrm{d}}$ & $9.55^{\mathrm{b}}$ \\
\hline $\mathrm{WA}_{\text {Total }}$ & $\mathrm{mg} \mathrm{H}_{2} \mathrm{O} \mathrm{g}^{-1}$ & $28.01^{\mathrm{acc}}$ & $14.31^{\mathrm{c}}$ & $17.89^{\mathrm{c}}$ & $45.92^{\mathrm{a}}$ & $42.02^{\mathrm{ab}}$ & $23.94^{\text {bc }}$ & $16.59^{\mathrm{c}}$ \\
\hline
\end{tabular}

Note. Means followed by the same letter within a row are not statistically different, according to the Tukey test at $5 \%$ probability. Total porosity $\left(\mathrm{P}_{\text {Total }}\right)$, macroporosity $\left(\mathrm{Macro}_{\mathrm{P}}\right)$, microporosity $\left(\mathrm{Micro}_{\mathrm{P}}\right)$, field capacity at $33 \mathrm{kPa}$ (FC), permanent wilt point at $1500 \mathrm{kPa}(\mathrm{PWP})$ and total soil water availability $\left(\mathrm{WA}_{\text {Total }}\right)$.

The total porosity was affected by biochar rates, in which higher the biochar rates are, higher is the total porosity. Similar effects were reported by Glab et al. (2016), using biochar formulated with straw of two species, miscanthus and winter wheat. Hardie et al. (2014) suggested that biochar may induce to changes in soil porosity and water retention due to three mechanisms: direct interference of biochar pores, creation of accomodation pores between biochar particles and soil aggregates and a higher persistence of soil pores by promoting agreggate stability.

The CSB at $2 \%$ had the highest values for FC and PWP, with a increase of 5.16 and $6.18 \%$ compared to the control. The water hold capacity in the soil is related to its porosity. The effects of biochar on FC, PWP and $\mathrm{WA}_{\text {Total }}$ were variable for different biochar types, similar was verified by Sun and Lu (2014). However, Biochar application had no significant increase on water avalability, compared to the control. This fact may be related with the increase of a small pores, reflecting in Microp values that raised, especially in CSB at 1 and $2 \%$.

\subsection{Effects of Biochar on Seedling Growth Parameters}

The effects of biochar on seedling growth parameters along the time, after 30, 45, 60 and 75 days after sowing is represented in Figure 1. Evaluating biochar effects on shoot height 30 days after sowing had significant differences among the treatments. The control had the highest values for this parameter, however from 45 to 75 days after sowing all biochar treatments had no diferences. In the last evaluation, SSB at $2 \%$ increased $10.5 \mathrm{~cm}$ of shoot height, compared to the control. From 60 days after sowing, SSB at $2 \%$ also stood out for having the highest values of stem base diameter. Number of leaves had a siginificant decrease with CSB at $2 \%$ application and $\mathrm{OBB}$ at $2 \% 45$ and 75 days after sowing, respectively. 

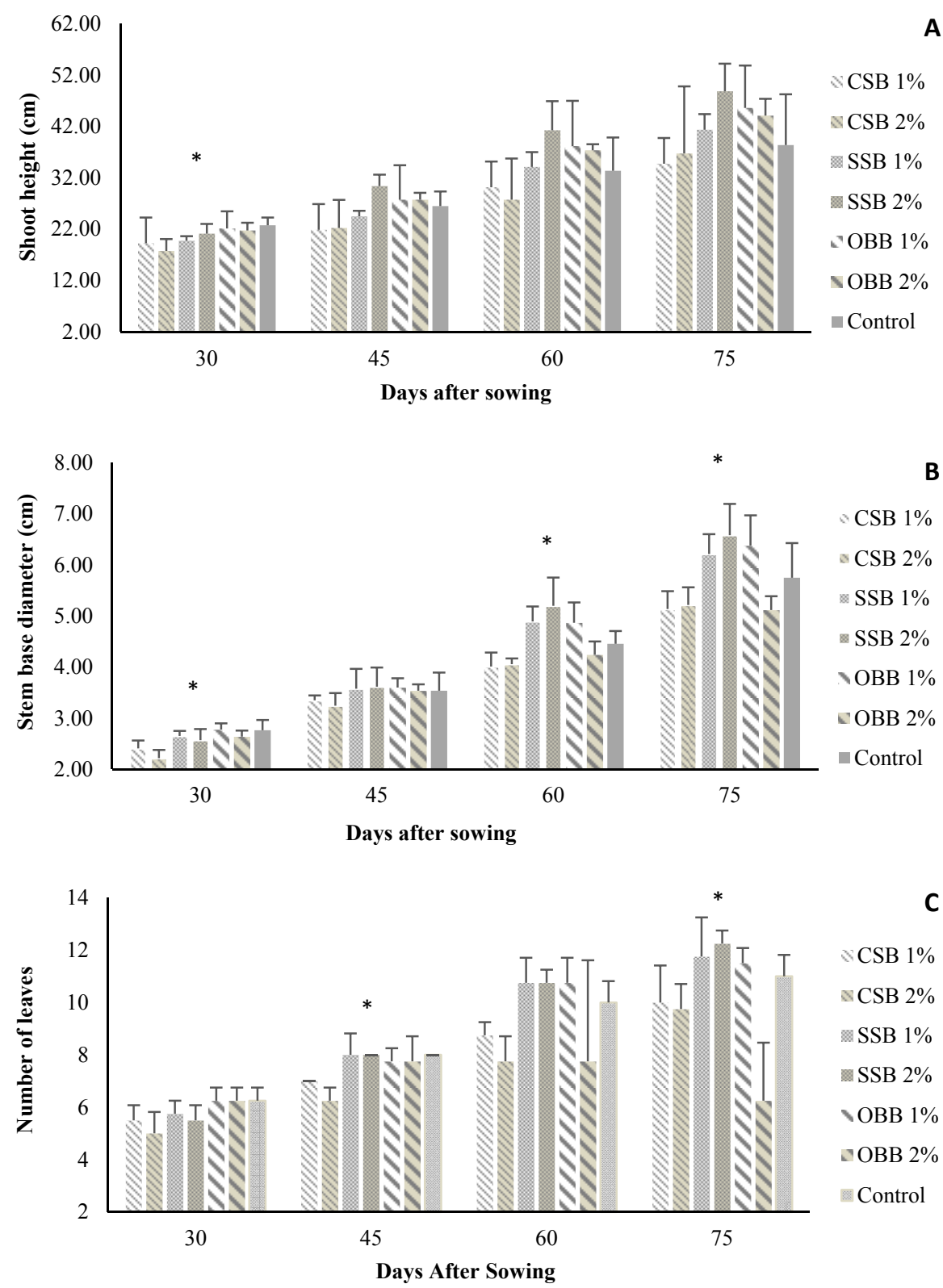

CSB $1 \%$

$\triangle \mathrm{CSB} 2 \%$

$\approx$ SSB $1 \%$

¿SSB $2 \%$

$\checkmark$ OBB $1 \%$

$\triangle \mathrm{OBB} 2 \%$

- Control

Days after sowing

A

C

$\triangle \mathrm{CSB} 1 \%$

$\triangle \mathrm{CSB} 2 \%$

SSB $1 \%$

SSB $2 \%$

○ВB $1 \%$

-OBB $2 \%$

- Control

Figure 1. Shoot height (A), Stem base Diamter (B) and Number of leaves (C) of Moringa oleifera substrates treated with biochar form coconut shell (CSB), orange bagasse (OBB) and sewage sludge (SSB), at 1 and $2 \%$ after 30, 45, 60 and 75 days after sowing. Note error bars indicate \pm standard deviation. The asterisk indicates the significant difference $(\mathrm{p}<0.05)$ according Tukey test among treatments

Biochar amendment signficantly increased steam base diameter (SBD) and shoot dry matter (SDM) (Table 5). The biochar type SSB at 1 and $2 \%$ and OBB at $1 \%$ had the highest means of SBD, with an increase of $0.46,0.83$ and $0.62 \mathrm{~mm}$ compared to the control, respectively. However, only SSB at $2 \%$ had the highest value of SDM, compared to the control. Raising biochar concentration at $2 \%$ of type OBB, there is a reduction of these parameters expression, showing statistically similar results compared to the contol. Same behavior was observed for the TDM, in which increasing OBB concentration from 1 to $2 \%$ caused reduction of 1.7 g.plant ${ }^{-1}$. Stem base diameter is considered a great parameter to estimate forest seedling survival at field conditions, mainly because it is easy to measure and is non-destructive. The larger stem base diameter, the better is shoot growth balance (Gomes \& Paiva 2013). 
Table 5. Growth parameters of $M$. oleifera substrates treated with biochar form coconut shell (CSB), orange bagasse (OBB) and sewage sludge (SSB), at 1 and $2 \%$

\begin{tabular}{|c|c|c|c|c|c|c|c|}
\hline \multirow{2}{*}{ Growth Parameters } & \multicolumn{7}{|c|}{ Biochar Treatment } \\
\hline & Control & CSB 1\% & CSB $2 \%$ & SSB $1 \%$ & SSB $2 \%$ & OBB $1 \%$ & OBB $2 \%$ \\
\hline SBD (mm) & $5.75^{\mathrm{b}}$ & $5.13^{\mathrm{b}}$ & $5.21^{\mathrm{b}}$ & $6.21^{\mathrm{a}}$ & $6.58^{\mathrm{a}}$ & $6.37^{\mathrm{a}}$ & $5.11^{\mathrm{b}}$ \\
\hline $\mathrm{SH}(\mathrm{mm})$ & $383.7^{\mathrm{a}}$ & $347.5^{\mathrm{a}}$ & $367.5^{\mathrm{a}}$ & $413.7^{\mathrm{a}}$ & $488.7^{\mathrm{a}}$ & $456.2^{\mathrm{a}}$ & $441.2^{\mathrm{a}}$ \\
\hline NF & $11.00^{\mathrm{a}}$ & $10.00^{\mathrm{a}}$ & $9.75^{\mathrm{a}}$ & $11.75^{\mathrm{a}}$ & $12.25^{\mathrm{a}}$ & $11.50^{\mathrm{a}}$ & $6.25^{\mathrm{b}}$ \\
\hline SDM (g. planta ${ }^{-1}$ ) & $2.27^{\mathrm{b}}$ & $1.81^{\mathrm{c}}$ & $1.72^{\mathrm{c}}$ & $2.47^{\mathrm{b}}$ & $3.15^{\mathrm{a}}$ & $2.52^{\mathrm{b}}$ & $1.70^{\mathrm{c}}$ \\
\hline RDM (g planta ${ }^{-1}$ ) & $2.68^{\mathrm{a}}$ & $2.17^{\mathrm{a}}$ & $2.26^{\mathrm{a}}$ & $3.37^{\mathrm{a}}$ & $3.20^{\mathrm{a}}$ & $2.96^{\mathrm{a}}$ & $2.07^{\mathrm{a}}$ \\
\hline TDM (g planta ${ }^{-1}$ ) & $4.95^{\mathrm{a}}$ & $3.98^{\mathrm{b}}$ & $3.98^{\mathrm{b}}$ & $5.84^{\mathrm{a}}$ & $6.35^{\mathrm{a}}$ & $5.48^{\mathrm{a}}$ & $3.78^{\mathrm{b}}$ \\
\hline
\end{tabular}

Note. Means followed by the same letter within a row are not statistically different, according to the Tukey test at $5 \%$ probability. Strem base diameter (SBD), Shoot height (SH), Number of leaves (NF), Shoot dry matter (SDM), Root dry matter (RDM), Total dry matter (TDM).

The SSB at $1 \%$ improved SDM in 0.88 g.plant $^{-1}$, compared to the control. A number of researchers have suggested that biochar amendment had positive effects on forest seedlings growth (Petter et al., 2012; Rezende et al., 2016; Souchie et al., 2011). Shouchie et al. (2011) studied the biochar application produced with Eucalyptus $s p$. in forest seedlings substrates showed an increase in seedling height, diameter and dry matter. However, this effect was observed just starting with biochar concentration of $12.5 \%$.

There was no statistically differences among the treatments for the variables SH and RDM. Theses results are in accordance with Neves et al. (2010) findings, in which organic materials for M. oleifera seedlings subtrates had no different effects among the treatments using coconut and sewage sludge. Similar findings were reported by Lima et al. (2016) using Eucalyptus sp. wood for beet production. The SSB biochar type at $2 \%$ had the highest means for all seedling growth variables, being recommend by Gonzaga et al. 2018 as a soil condiotioner for improving Eucalyptus seedling growth.

The material type used in substrates composition for seedlings production directly influences on compound physical characteristics. Normally, improving these physical characteristics leads to a better seedling growth. It may be noticed that the sewage sludge substrate using a dose of $2 \%$ provided a significant increase in the amount of water available in the soil (Table 4). Probably, it provoked a greater stem base diameter and leaves number increase, 45 days after sowing (Figure 1 and Table 5). Although the seedlings development is directly related to the substrates physical characteristics, improving substrate chemical characteristics may also lead to a better plants development. Table 3 shows that the sewage sludge biochar at a dose of $2 \%$ presented a higher phosphorus concentration, which may have contributed to the increase seedlings performance under this treatment (Figure 1 and Table 5). In addition, all biochars caused, in general, an increase of carbon concentration relative to the control (Table 3). This fact may also have influenced the greater seedling growth in the sewage sludge biochar.

The seedlings quality indexes are showed in Table 6 . It is noted that the quality indexes had no significant differences among biochar treatments. So that, the biochar types used did not influence in the quality of $M$. Oleifera seedlings. These findings corroborate with results observed by Lima et al. (2016). M. oleifera is a rustic plant and this fact could be limited the biochar expression in the seedlings.

Table 6. Quality Indexes of Moringa oleifera substrates treated with biochar form coconut shell (CSB), orange bagasse (OBB) and sewage sludge (SSB), at 1 and $2 \%$

\begin{tabular}{llllllll}
\hline \multirow{2}{*}{ Quality Indexes } & \multicolumn{7}{c}{ Biochar treatment } \\
\cline { 2 - 7 } & Control & CSB 1\% & CSB 2\% & SSB 1\% & SSB 2\% & OBB 1\% & OBB 2\% \\
\hline SH/SBD & $6.73^{\mathrm{a}}$ & $6.94^{\mathrm{a}}$ & $6.68^{\mathrm{a}}$ & $7.43^{\mathrm{a}}$ & $7.26^{\mathrm{a}}$ & $8.66^{\mathrm{a}}$ & $6.59^{\mathrm{a}}$ \\
RDM/SDM & $0.91^{\mathrm{a}}$ & $0.78^{\mathrm{a}}$ & $0.77^{\mathrm{a}}$ & $1.12^{\mathrm{a}}$ & $0.91^{\mathrm{a}}$ & $0.85^{\mathrm{a}}$ & $0.85^{\mathrm{a}}$ \\
DQI & $0.54^{\mathrm{a}}$ & $0.56^{\mathrm{a}}$ & $0.79^{\mathrm{a}}$ & $0.74^{\mathrm{a}}$ & $0.69^{\mathrm{a}}$ & $0.40^{\mathrm{a}}$ & $0.69^{\mathrm{a}}$ \\
\hline
\end{tabular}

Note. Means followed by the same letter within a row are not statistically different, according to the Tukey test at $5 \%$ probability. Shoot height/Stem base diameter (SH/SBD), Root dry matter/Shoot dry matter (RDM/SDM), Dickson quality index (DQI). 
The DQI varied from 0.40 to 0.79 , being considered as the good quality seedlings for field conditions. According to Gomes and Paiva (2004), the higher DQI value is, higher is seedlings quality and values below 0.2 are not considered good for taking in account field contions. The DQI represents a promising weighted morphological measure, since it consideres not only the seedling vigor, but also plant biomass distribution (Merlo et al., 2008). As biochar concentrtation increased, SH/SBD and RDM/SDM indexes also increased. The RDM/SDM index is an important parameter to evaluate when the seedlings are ready to be submitted to field conditions. Plant shoot should not be much higher to roots due to occurance problems in water absorption for the stem (Caldeira et al., 2008).

\section{Conclusions}

The application of biochar improved physical and chemical soil properties, although the effect is not always siginificant. The different biochar types affected positively growth parameter of M. oleifera seedlings. In general, the sewage sludge application is highlighted for having the greatest values for most of the analyzed parameters.

\section{References}

ABNT (Associação Brasileira de Normas Técnicas). (1986). Carvão Vegetal-Análise Imediata. NBR-8112 (MB1857).

Abujabhah, I. S., Doyle, R., Bound, S. A., \& Bowman, J. P. (2016). The effect of biochar loading rates on soil fertility, soil biomass, potential nitrification, and soil community metabolic profiles in three different soils. Journal of Soils and Sediments, 16(9), 2211-2222. https://doi.org/10.1007/s11368-016-1411-8

Agustini, M. A. B., Wendt, L., Paulus, C., \& Malavasi, M. M. (2015). Maturidade fisiológica de sementes de Moringa oleifera. Revista Inova Ciência \& Tecnologia, 1(1), 11-17.

Caldeira, M. V. W., Rosa, G. N., Fenilli, T. A. B., \& Harbs, R. M. P. (2008). Composto orgânico na produção de mudas de aroeira-vermelha. Scientia Agraria, 9(1), 27-33. https://doi.org/10.5380/rsa.v9i1.9898

Carneiro, J. G. A. (1995). Produção e controle de qualidade de mudas florestais (p. 451). Curitiba: UFPR/FUPEF/UNEF.

Dai, Z., Meng, J., Muhammad, N., Liu, X., Wang, H., He, Y., Brookes, P. C., \& Xu, J. (2013). The potential feasibility for soil improvement, based on the properties of biochars pyrolyzed from different feedstocks. Journal of Soils and Sediments, 13(6), 989-1000. https://doi.org/10.1007/s11368-013-0698-y

Dickson, A., Leaf, A. L., \& Hosner, J. F. (1960). Quality appraisal of white spruce and white pine seedling stock in nurseries. Forest Chronicle, 36(1), 10-13. https://doi.org/10.5558/tfc36010-1

Ding, Y., Liu, Y., Liu, S., Li, Z., Tan, X., Huang, X., \& Zheng, B. (2016). Biochar to improve soil fertility: A review. Agronomy for Sustainable Development, 36. https://doi.org/10.1007/s13593-016-0372-z

Donagema, G. K., Campos, D. V. B., Calderano, S. B., Teixeira, W. G., \& Viana, J. H. M. (2011). Manual de métodos de análise de solos (2nd ed., p. 230). Rio de Janeiro: Embrapa Solos.

Głąb, T., Palmowska, J., Zaleski, T., \& Gondek, K. (2016). Effect of biochar application on soil hydrological properties and physical quality of sandy soil. Geoderma, 281, 11-20. https://doi.org/10.1016/j.geoderma. 2016.06.028

Gomes, J. M., \& Paiva, H. N. (2004). Viveiros florestais: Propagacão sexuada (3rd ed., p. 116). Vicosa, MG: Editora UFV.

Gonçalves J. L. M., \& Poggiani F. (1996). Substrato para produção de mudas florestais. Resumos do Congresso Latino Americano de Ciência do Solo. Águas de Lindóia. Piracicaba: Sociedade Latino Americano de Ciência do Solo.

Gonzaga, M. I. S., Mackowiak, C., de Almeida, A. Q., \& Júnior, J. I. T. de C. (2018). Sewage sludge derived biochar and its effect on the growth and morphological traits of Eucalyptus grandis W.Hill ex maiden seedlings. Ciencia Florestal, 28(2), 687-695. https://doi.org/10.5902/1980509832067

Hansen, V., Müller-Stöver, D., Munkholm, L. J., Peltre, C., Hauggaard-Nielsen, H., \& Jensen, L. S. (2016). The effect of straw and wood gasification biochar on carbon sequestration, selected soil fertility indicators and functional groups in soil: An incubation study. Geoderma, 269, 99-107. https://doi.org/10.1016/j.geoderma. 2016.01.033

Hardie, M., Clothier, B., Bound, S., Oliver, G., \& Close, D. (2014). Does biochar influence soil physical properties and soil water availability? Plant and Soil, 376(1-2), 347-361. https://doi.org/10.1007/s11104-013-1980-x 
Kloss, S., Zehetner, F., Wimmer, B., Buecker, J., Rempt, F., \& Soja, G. (2014). Biochar application to temperate soils: effects on soil fertility and crop growth under greenhouse conditions. Journal of Plant Nutrition and Soil Science, 177(1), 3-15. https://doi.org/10.1002/jpln.201200282

Lima, S. L., Marimon-Junior, B. H., Tamiozzo, S., Petter, F. A., Marimon, B. S., \& Abreu, M. F. (2016). Biochar added to a red oxisol benefits the sugar beet seedlings development? Comunicata Scientiae, 7(1), 97-103. https://doi.org/10.14295/cs.v7i1.787

Lima, S. L., Tamiozzo, S., Petter, F. A., Marimon, B. S., \& Marimon-Junior, B. M. (2013). Desenvolvimento de mudas de beterraba em substratos comerciais tratados com biochar. Agrotrópica, 25(3), 181-186. https://doi.org/10.21757/0103-3816.2013v25n3p181-186

MAPA (Ministério da Agricultura, Pecuária e Abastecimento). (2007). Métodos analíticos oficiais para análise de substratos para plantas e condicionadores de solo. Instrução normativa SDA n. 17. Diário Oficial da União, Brasília, DF.

Melo, R. R., Cunha, M. do C. L., Junior, F. R., Stangerlin, D. M. (2008). Crescimento inicial de mudas de Enterolobium contortisiliquum (Vell.) Morong. sob diferentes níveis de luminosidade. Revista Brasileira Ciências Agrárias, 3(2), 138-144. https://doi.org/10.5039/agraria.v3i2a263

Neves, J. M. G., Silva, H. P. da, \& Duarte, R. F. (2010). Use of alternative substrates for production of seedlings Moringa. Revista Verde, 5, 173-177.

Novak, J. M., Cantrell, K. B., Watts, D. W., Busscher, W. J., \& Johnson, M. G. (2014). Designing relevant biochars as soil amendments using lignocellulosic-based and manure-based feedstocks. Journal of Soils and Sediments, 14(2), 330-343. https://doi.org/10.1007/s11368-013-0680-8

Petter, F. A., \& Madari, B. E. (2012). Biochar: Agronomic and environmental potential in Brazilian savannah soils Revista Brasileira de Engenharia Agrícola e Ambiental, 16(7), 761-768. https://doi.org/10.1590/S1415-436 62012000700009

Petter, F. A., Ribeiro Andrade, F., Marimon Junior, B. H., Gonçalves, L. G., \& Schossler, T. R. (2012). Biochar como condicionador de substrato para a produção de mudas de eucalipto. Revista Caatinga, 25(4), 44-51.

Pratiwi, E. P. A., \& Shinogi, Y. (2016). Rice husk biochar application to paddy soil and its effects on soil physical properties, plant growth, and methane emission. Paddy and Water Environment, 14(4), 521-532. https://doi.org/10.1007/s10333-015-0521-z

R Development Core Team. (2015). R: A language and environment for statistical computing. Vienna. Austria: R Foundation for Statistical Computing. Retrieved from http://r-project.org

Rezende, F. A., Santos, V. A. H. F. dos, Maia, C. M. B. de F., \& Morales, M. M. (2016). Biochar in substrate composition for production of teak seedlings. Pesquisa Agropecuária Brasileira, 51(9), 1449-1456. https://doi.org/10.1590/s0100-204x2016000900043

Santos, W. R., Matos, D. B., Oliveira, B. M., Santana, T. M., Santana, M. M., \& Silva, G. F (2011). Estudo do tratamento e clarificação de água com torta de sementes de Moringa oleífera Lam. Revista Brasileira de Produtos Agroindustriais, 13(3), 293-297. https://doi.org/10.15871/1517-8595/rbpa.v13n3p295-299

SEMARH/SRH. (2013). Atlas Digital Sobre Recursos Hidricos do Estado de Sergipe. Aracaju, Sergipe: Secretaria de Meio Ambiente e Recursos Hídricos/Superintendencia de Recursos Hídricos.

Silva, E. A., Oliveira, A. C., Mendonça, V., \& Meneses Soares, F. (2011). Substratos na produção de mudas de mangabeira em tubetes. Pesquisa Agropecuária Tropical, 41(2), 279-285. https://doi.org/10.5216/pat. v41i2.9042

Silva, F. C. (2009). Manual de análise química de solos, plantas e fertilizantes (p. 627). Brasília: Embrapa Solos.

Souchie, F. F., Junior, B. H. M., Petter, F. A., Madari, B. E., Marimon, B. S., \& Lenza, E. (2011). Carvão pirogênico como condicionante para substrato de mudas de Tachigali vulgaris L. G. Silva \& H. C. Lima. Ciência Florestal, 21(4), 811-821. https://doi.org/10.5902/198050984526

Sun, F., \& Lu, S. (2014). Biochars improve aggregate stability, water retention, and pore-space properties of clayey soil. Journal of Plant Nutrition and Soil Science, 177(1), 26-33. https://doi.org/10.1002/jpln. 201200639

Tomé Júnior, J. B. (1997). Manual para interpretacão de análise de solo (p. 247). Guaíba: Agropecuária. 
Trazzi, P. A., Leahy, J. J., Hayes, M. H. B., \& Kwapinski, W. (2016). Adsorption and desorption of phosphate on biochars. Journal of Environmental Chemical Engineering, 4(1), 37-46. https://doi.org/10.1016/j.jece. 2015.11.005

Vaccari, F. P., Maienza, A., Miglietta, F., Baronti, S., Di Lonardo, S., Giagnoni, L., \& Valboa, G. (2015). Biochar stimulates plant growth but not fruit yield of processing tomato in a fertile soil. Agriculture, Ecosystems \& Environment, 207, 163-170. https://doi.org/10.1016/j.agee.2015.04.015

Vieira, H., Chaves, L. H. G., \& Viégas, R. A. (2008). Crescimento inicial de moringa (Moringa oleifera Lam) sob omissão de nutrientes. Revista Caatinga, 21(4), 51-56.

Zhang, Y., Tan, Q., Hu, C., Zheng, C., Gui, H., Zeng, W., ... Zhao, X. (2015). Differences in responses of soil microbial properties and trifoliate orange seedling to biochar derived from three feedstocks. Journal of Soils and Sediments, 15(3), 541-551. https://doi.org/10.1007/s11368-014-1032-z

\section{Copyrights}

Copyright for this article is retained by the author(s), with first publication rights granted to the journal.

This is an open-access article distributed under the terms and conditions of the Creative Commons Attribution license (http://creativecommons.org/licenses/by/4.0/). 